\title{
Raízes da Filosofia da Educação
}

RODRIGO, L. M. Platão e o debate educativo na Grécia Clássica. Campinas, SP: Autores Associados, 2014.

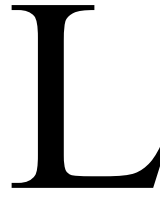

idia Maria Rodrigo é licenciada em Filosofia pela PUCCAMP, mestre em Filosofia da Educação pela UNIMEP, doutora em Filosofia pela UNICAMP. Lecionou nas universidades PUCCAMP, UNIMEP e UFU. Atualmente é professora no Departamento de Filosofia e História da Educação (DEFHE) da Faculdade de Educação da UNICAMP. O livro Platão e o debate educativo na Grécia clássica, objeto desta resenha, é fruto de um projeto de pesquisa realizado entre os anos de 2009 e 2011. Esse projeto, além do livro, rendeu à pesquisadora sua Livredocência.*

A autora, no referido livro, mostra como se desenvolveu a educação na Grécia no período clássico (séculos IV e V a.C.). Para tanto, aponta serem três as concepções de educação que, nesse momento histórico, disputavam a hegemonia na formação do homem grego: a poética, a sofística e a filosófica. Como fio condutor para essa investigação, a autora prioriza esta última, ou, para sermos mais precisos, ela irá, a partir das críticas que Platão faz a essas paideias, reconstruir o conflito. Apesar disso, a autora não se satisfaz com a descrição platônica das teorias educacionais anteriores à sua, mas, ao contrário, convoca os mais renomados helenistas dos séculos XX e XXI para caracterizar essas paideias. Para falar da poética recorre a Detienne, Vernant, Jaeger, Eliade, Finley, entre outros.

\footnotetext{
Essas informações estão disponíveis no Currículo Lattes da pesquisadora (http://lattes.cnpq.br/3630284298508608).
}

Filosofia e Educação [rfe] - volume 7, número 3 - Campinas, SP

Outubro de 2015-Fevereiro de 2016 - ISSN 1984-9605 - p. 
A primeira e mais fundamental característica da primeira paideia está no seu caráter milenar. Os poetas, em especial Homero, guardavam na memória fatos ocorridos séculos antes da sua existência e que determinavam aspectos importantes da vida social. Assim, diz ela: "por detrás e por intermédio dos acidentes da história épica, o texto homérico destilava um conjunto de ensinamentos, desde valores éticos e modelos de comportamento humano, até conhecimentos técnicos sobre culinária, medicina, confecção de artefatos, mantendo vivas, portanto, as normas que regiam o comportamento do grupo" (p.14). Além disso, continua ela, "o poeta estava investido de dupla incumbência: celebrar os mortais, as façanhas dos heróis, dos homens corajosos, e também os Imortais, isto é, contar a história dos deuses" (p.14). Assim, o poeta possuía em suas mãos o natural e o sobrenatural, as histórias dos homens e dos deuses, e, por meio da sua maneira de contá-las, mantinha viva as tradições e os costumes.

A segunda paideia, a sofística, que começou sua atuação no final do período arcaico (séculos VIII e VII), com a organização e o crescimento das cidades, trouxe a esse período novas configurações. Como na paideia anterior, a autora convoca os estudiosos desse movimento educacional para caracterizá-lo, entre eles Cassin, Reboul, Guthrie, Kerferd. Os sofistas, que nada mais são do que professores itinerantes, ofereciam aos seus alunos conhecimentos que até então eram destinados apenas à nobreza. Por causa disso, de certo modo, eles democratizaram o saber, contribuindo para a construção da democracia grega. A autora destaca que eles atuaram principalmente em três modalidades educativas: a) a educação como transmissão de um saber enciclopédico, com Hípias de Élis como seu maior representante; b) a educação baseada na retórica, cujo maior nome é Gorgias de Leontini; c) a educação moral e política, com Protágoras de Abdera como referência (p.59-60). Para concluir essa seção, Rodrigo, citando Jaeger, 
afirma que os sofistas foram os fundadores da pedagogia, fornecendo para nós ainda hoje referências na nossa maneira de educar.

Se, por um lado, Rodrigo tenta descrever as paideias poéticas e sofísticas sem o auxílio de Platão, por outro não deixa de recorrer ao filósofo ateniense para apresentar as críticas que aqueles sofreram no período clássico. Todavia, apesar das pesadas críticas, a paideia platônica não excluiu as paideias anteriores; pelo contrário, sustenta a autora (e talvez aí esteja a diferença desse seu trabalho em relação aos de outros pesquisadores de mesmo tema), o projeto educacional platônico é dependente dos projetos educacionais dos poetas e dos sofistas.

Da paideia poética, Platão vai apropriar-se de dois conceitos fundamentais: o paradigma (modelo) e a mimesis (imitação). Isso porque, na poesia homérica, a partir das narrações das ações dos deuses e dos heróis, os mortais comuns tinham neles um ideal de virtude (arete) a seguir. Platão, então, utiliza-se desse procedimento, isto é, da criação de um modelo ideal de comportamento para criticar a descrição que os poetas faziam das divindades e dos heróis. Em outros termos, os deuses e os heróis descritos pela poesia grega, para Platão, não eram suficientemente ideais para serem modelos para os homens; é preciso torná-los mais perfeitos.

A autora enfatiza que a poesia no projeto educacional platônico (descrita na República), possui dois momentos distintos: nos livros II e III, relativo à educação dos guardiões; e no livro $\mathrm{X}$, quanto à educação do governante. No primeiro momento, voltado à educação dos guerreiros e soldados, deviam ser excluídos os trechos que contribuem para a má formação deles, isto é, trechos que provoquem a temeridade e a impiedade (p.40-41). No segundo momento, reservado à formação do filósofo governante, a poesia deve ser excluída, uma vez que ela está três níveis distante da realidade, confundindo o intelecto dele (p.46) 
A respeito da paideia sofística, a autora diz que Platão não é menos crítico: para Hípias Platão afirma que a matemática não pode estar a serviço do saber enciclopédico, aplicado apenas às técnicas, mas no seu poder abstrato de elevação do espírito. Contra os retóricos, Platão defende que a verdadeira retórica é aquela baseada na verdade e não nas aparências. Já a Protágoras, que se julga capaz de ensinar a virtude a todo homem, Platão afirma que ele não possui um fundamento sólido, uma vez que o sofista não considera a virtude como ciência, o que, para o filósofo, impossibilita seu ensino (p.61)

Para completar sua descrição da paideia platônica, Lidia vai apresentar o que Platão herdou da filosofia socrática: o protreptiko (exortação) e o elenkos (indagação). No primeiro, diz ela, "Sócrates convida e estimula seu interlocutor a buscar a verdade sobre determinado tema" (p.85). No segundo, "ele faz perguntas, comenta e refuta as respostas do interlocutor, volta a formular novas perguntas, insistindo em repetidas tentativas para chegar ao conceito geral que se buscava" (p.85).

Sendo assim, a partir das três paideias, Platão constrói a sua: aquela que mostra a existência das ideias. Essa teoria defende que tudo no sensível possui uma essência correspondente. Essas essências, diz a autora, "situamse numa instância superior e distinta do nosso mundo, pois o mundo em que vivemos é o lugar das coisas mutáveis e perecíveis. As ideias, como puras formas, imateriais, incorruptíveis e eternas, existem no Mundo das Ideias ou Mundo inteligível [...] o mundo das ideias é o mundo da ciência e da verdade" (p.103). Assim, conhecendo as ideias, o filósofo, o único que depois de um longo período de educação consegue atingi-las, pode construir a constituição perfeita e educar os homens de maneira plena.

A título de conclusão pensamos que, com seu livro, a autora tenta mostrar as raízes da filosofia educacional do ocidente: aquela que se 
preocupa com a tradição e os costumes (poética); aquela que se ocupa com a moral, o ensino da linguagem e da matemática (sofística); e finalmente aquela que busca a união das anteriores por intermédio das ciências e do entendimento do inteligível (filosófica). 